INDEXING OPEN ACCESS LAW JOURNALS...OR MAYBE NOT

\author{
INTERNATIONAL JOURNAL OF LEGAL INFORMATION \\ VOL. 38/NO.1/SPRING 2010
}

\author{
EDWARD T. HART \\ University of North Texas at Dallas \\ College of Law
}




\title{
Indexing Open Access Law Journals, or Maybe Not
}

\author{
Edward T. Hart*
}

\section{Introduction}

At the 2007 Charleston Conference, Elaine Yontz and Jack Fisher, library science professor and librarian respectively at Valdosta State University, gave a presentation on their study of indexing by the leading information science indexers of the seventy-eight open access journals $(\mathrm{OAJ})$ listed for library and information science in the Directory of Open Access Journals (DOAJ). Their discovery was that less than $47 \%$ of the journals listed in the DOAJ were indexed. ${ }^{1}$ Additional observations made were the relative newness of many of the library science journal titles listed in DOAJ, the breath of the languages in which OAJ were being of published, and the quality of many the publishers or groups behind the journals. ${ }^{2}$ Yontz and Fisher are concerned that American scholars overlook these potentially helpful journals because of the lack of indexing.

The concern over lack of indexing OAJ is shared. Katherine Bell of the University of Windsor wrote in 2009 about indexing of business journals contained in the DOAJ. ${ }^{3}$ Of the then

\footnotetext{
* Assistant University Librarian and Head of Technical Services, Lawton Chiles Legal Information Center, Levin College of Law, University of Florida, Gainesville, FL, U.S.A. Thanks to Elaine Yontz and Jack Fisher for the idea and for the opportunity to present on this topic with them at the 2009 Charleston Conference, Michelle Pearse for our conversations about open access legal journals, and my colleagues Elizabeth Outler, Patricia Morgan, Christopher Vallandingham, and Bronwyn McCarthy.

${ }^{1}$ Elaine Yontz and Jack Fisher, "Are They Being Indexed? Tracking the Indexing and Abstracting of Open Access Journals, Charleston Conference Proceedings 2007, 126-130.

2 Ibid.

${ }^{3}$ Katherine Bell, "The Indexing of Scholarly Open Access Business Journals," 10 Electronic Journal of Academic and Special Librarianship (2009). See also E. A. Nowick, C. A. Jenda, \& J. Azzam, "Indexing of Open Access Journals in Agriculture," 49 IAALD Quarterly Bulletin 20 (2004).
} 
83 titles listed, the most indexed was 36, or $43 \% .^{4}$ Bell believes that, "In order for the increasing number of open access ... journals to achieve credibility and flourish ... it is not enough to simply be published and freely available on the Internet. Researchers need a means to be able to systematically search across the broad spectrum of ... journals, and retrieve the articles in their particular areas of research and study." Without indexing there is a lack of access that that cannot be overcome by keyword searching.

Yontz and Fisher's presentation naturally caused this author to wonder, what would be the results of a similar study of the law journals listed in the DOAJ? That is what the author set out to discover the answer. Below is a brief description of scholarly open access publishing and the Directory, a look at the law journals listed in the DOAJ, standards for selection of journals for indexing in the four primary indexes used in United States legal research, results of the study of inclusion of DOAJ law journals in these four indexes, and a conclusion that considers what the impact of indexing or not indexing open access journals means on legal research.

\section{Directory of Open Access Journals}

As an introduction for some, and a refresher for others, the Directory of Open Access Journals is a non-profit effort headed up by Lund University Libraries. The directory can be found at the address www.doaj.org. The DOAJ defines open access journals "as journals that use a funding model that does not charge readers or their institutions for access." The statement from the Directory founders continue, "From the BOAI [Budapest Open Access Initiative] definition of 'open access' we take the right of users to 'read, download, copy, distribute,

\footnotetext{
${ }^{4} \mathrm{Id}, 4$.

${ }^{5}$ Ibid.
} 
print, search, or link to the full texts of these articles' [emphasis original] as mandatory for a journal to be included in the directory." ${ }^{\circ 6}$ But it takes more than just open access to be included in the Directory. For an OAJ to be listed in the Directory it must exercise quality control, such as peer review, and publishes research articles in a regular manner usually at least once a year in consecutively numbered or dated issues.

The DOAJ is a great tool for those that know of its existence. This author only became aware of its existence after the electronic acquisitions librarian at the University of Florida (UF) Smathers Libraries added DOAJ to be tracked by Serial Solution, and that service began populating our OPAC with records of law OAJ. For librarians DOAJ provides a central clearinghouse of OAJ. It also provides two other services: a search engine that crawls through the content of many of the open access titles listed and metadata which librarians can use in their own catalogs to connect their user communities to the titles in the Directory.

DOAJ is a leading innovator of access, and its work is recognized by the scholarly community including receiving the 2009 Europe SPARC Award. ${ }^{7}$

The Directory lists seventeen broad subject areas as the top layer of its expandable subject tree. For Yontz and Fisher's titles of interest, Library and Information Science, is a secondary level entry under Social Sciences. Law is paired with Political Science as one broad, top level subject area. Clicking through to the next level, the two subjects are split allowing

\footnotetext{
${ }^{6}$ Directory of Open Access Journals, About available at http://www.doaj.org/doaj?func=loadTempl\&templ=about citing Budapest Open Access Initiative, Frequently Asked Questions available at http://www.earlham.edu/ peters/fos/boaifaq.htm\#openaccess (last visited 9 June 2010) ${ }^{7}$ SPARC Europe, "The Directory of Open Access Journals Receives SPARC Europe Award for Outstanding Achievements in Scholarly Communications, 2009 " is available at http://www.sparceurope.org/news/thedirectory-of-open-access-journals-receives-sparc-europe-award-for-outstanding-achievements-in-scholarlycommunications-2009 (last visited 9 June 2010)
} 
legal scholars to focus on just the titles related to this subject. The number of Law OAJ titles has varied some over the two years this author has pondered the question. At the time of my survey June 2009, there were sixty-one titles.

\section{Law Journals in DOAJ}

The seventy-seven law titles in the directory run a gambit of entries. They geographically represent twenty countries from Chile to Canada, Australia long way around to India. ${ }^{8}$ Common law and civil law traditions are both represented. Most represented in title count is the United States with an interesting three way tie for second place between Chiles, Spain, and United Kingdom. OAJ are published in ten languages. ${ }^{9}$ While English is common, used by both native speakers and adopting non-English speakers as a language of scholarly transmittal, small language populations speaking Catalan and Afrikaans are also represented.

Sponsoring institutions of the law OAJ are mostly universities, but include learned societies and private publishers in the mix. Duke University School of Law has the most titles in the directory as that law school promotes open access for all its publications. ${ }^{10}$

\footnotetext{
${ }^{8}$ Countries include Australia, Brazil, Canada, Chile, Columbia, Denmark, Estonia, Germany, Great Britain, India, Italy, Mexico, Netherlands, Peru, Romania, South Africa, Spain, Switzerland, United States, Venezuela ${ }^{9}$ Languages are Afrikaans, Catalan, Dutch, English, Estonian, French, German, Italian, Portuguese, and Spanish. ${ }^{10}$ See Richard A. Danner, "Applying the Access Principle in Law: The Responsibilities of the Legal Scholar," 35 Int'l J. of Legal Information 355-395 (2007).
} 


\section{Indexes in U.S. Legal Research}

The four most widely held and used indexes in the U.S. are Index to Legal Periodicals and Books (ILP); Current Law Index (CLI), a.k.a LegalTrac; Current Index to Legal Periodicals (CILP), and the Index to Foreign Legal Periodicals (IFLP).

The Index to Legal Periodicals, to use its more common name, is published in both print and as an electronic database by the company H.W. Wilson. ${ }^{11}$ The index has been published for over fifty years and currently includes 1,025 legal serials among them law reviews, yearbooks, and bar associations publications. Retrospectively, Wilson indexed journals back to 1908 . Additionally, ILP in its electronic format provides full text access to 325 titles going back as far as 1994. Wilson is guided in its selection of what to index by its Editorial Advisory Committee whose members include law librarians from a cross section of law libraries and law faculty. Directions from Wilson provide that suggestions for adding and deleting titles that are indexed should be addressed to the committee care of the company.

Current Law Index is published by Gale, which is part of Cengage Learning, and the company offers this description of the product.

Current Law Index is a monthly publication that contains coverage of more than 900 key law journals, legal newspapers and specialty publications from the United States, Canada, the United Kingdom, Ireland, Australia and New Zealand. These sources provide information on the interpretation and analysis of laws, cases, statutes, legal trends and law firm management. Titles covered include academic reviews, bar association journals, specialty journals and selected journals treating allied disciplines such as

\footnotetext{
${ }^{11} \mathrm{H}$. W. Wilson Compnay, Index to Legal Periodicals, available at http://www.hwwilson.com/libretro/legal.cfm (last visited 9 June 2010).
} 
criminology, accounting, business, criminal, international law, taxation, estate planning and much more. Current Law Index, produced in cooperation with the American Association of Law Libraries, is the most comprehensive overview of law-related articles available in print and is the perfect companion to your current electronic reference databases. ${ }^{12}$

The electronic counterpart of this index is called LegalTrac. The cooperation with the American Association of Law Libraries (AALL) centers on the association's Indexing Legal Periodicals Committee. The committee has two duties, first it "reviews newly published legal periodicals and makes recommendations ... concerning inclusion of those titles in the Legal Resources Index/Current Law Index," and second, the committee considers, "Where the scope of periodical titles presently indexed does not adequately reflect the needs of the AALL membership, the Committee makes recommendations ... concerning the adjustment of that scope. " 13

The Current Index to Legal Periodicals is a weekly alert, now sent via email, indexing the most recent issues of 570 legal periodicals. CILP been compiled since 1948 by librarians and staff of the Marian Gould Gallagher Law Library at the University of Washington School of Law. $^{14}$

The Index to Foreign Legal Periodicals started in 1960 is published by the University Press of California for AALL and is compiled by an editorial staff housed in the law library at University of California, Berkeley. The editors of the index are advised on what to index by the

\footnotetext{
${ }^{12}$ Gale Cenage Learning, Current Law Index, available at http://www.gale.cengage.com/servlet/BrowseSeriesServlet?region=9\&imprint=000\&titleCode=CLI\&edition (last visited 9 June 2010).

${ }^{13}$ American Association of Law Libraries, Indexing of Periodical Literature Committee, Charge available at http://www.aall.org/committee/ipl com.asp (last visited 9 June 2010).

${ }^{14}$ Marian Gould Gallagher Law Library, Current Index to Legal Periodicals available at http://lib.law.washington.edu/cilp/cilp.html (last visited 9 June 2010)
} 
AALL Index to Legal Periodicals Committee. It indexes 470 journals from around the world focusing on international, comparative, and foreign law, jurisdictions other than the United States. The electronic edition of the index is provided by Ovid Technologies. This publication also has an AALL committee, Index to Foreign Legal Periodicals Committee, to advise it including "suggests [of] new journals to be indexed and revisions to the Index to Foreign Legal Periodicals." $" 15$

Each index has its own selection criteria for inclusion of journals into their products. How the criteria adopted to include or not include open access law journals is worth consideration before looking at the results of the study.

For the ILP, Wilson and its advisory committee set out fourteen points they consider for selection of titles to index. ${ }^{16}$ Some of the criteria are similar to DOAJ's in that the journals must be published annually and "e-journals should be of a scholarly nature, have stable content, be

\footnotetext{
${ }^{15}$ American Association of Law Libraries, Index to Foreign Legal Periodicals Committee, Charge available at http://www.aall.org/committee/iflp_com.asp (last visited 9 June 2010).

16 H. W. Wilson, Index to Legal Periodicals \& Books Editorial Advisory Committee Selection Policy (2003) SELECTION POLICY

- Include only periodicals with legal content.

- A periodical's content must be of high quality and have permanent reference value.

- Most of the periodical's content must consist of indexable articles of sufficient length, i.e. at least half a page.

- Periodicals must contain original articles rather than reprinted features.

- A periodical containing articles with footnotes and other scholarly apparatus is preferred over those with undocumented discussion.

- Periodicals must be in English or bilingual.

- Political orientation will not be considered as a criterion

- Avoid adding periodicals that are indexed in other Wilson indexes.

- Periodicals must be published at least annually and must have a regular publication schedule.

- A periodical supplied only to subscribers to another work or service is considered a supplement to that work and should not be included in ILP.

- Newsletters, loose-leaf services and newspapers are not considered.

- High-priced periodicals should have wide circulation and broad coverage.

- Periodicals available in full-text electronic formats are desirable.

- Periodicals available only in e-journal format online should be of a scholarly nature, have stable content, be produced by a reputable major publisher, and be archived.
} 
produced by a reputable major publisher, and be archived."17 More recently, Wilson amended its policies to review the selection of OAJ. ${ }^{18}$ This new policy seems to reaffirm Wilson's prior

\footnotetext{
${ }^{17} \mathrm{Ibid}$.

18 H. W. Wilson, OPEN ACCESS JOURNALS: SELECTION CRITERIA (2007)

The open access movement aims to put peer-reviewed scientific and scholarly literature on the Internet. It makes this literature available free of charge and free of most copyright and licensing restrictions. The goal is to remove barriers to serious research. An overview of open access concepts may be found at http://www.earlham.edu/ peters/fos/overview.htm.
}

As an important new mode of scholarly communication, open access journals deserve indexing. The following points should be considered before adding open access journals to an H.W. Wilson index:

- Open Access Status. Consider the following to be evidence of open-access status:

- Publication in electronic format only. Journals that publish parallel print and electronic editions should be treated as print journals for indexing purposes.

- No charge for access. Exclude any electronic journals that charge subscription or article-access fees.

- No mandatory registration barriers. H.W. Wilson e-journal links must be able to take users directly from WilsonWeb citations to the text of an article on the journal's website. Exclude any journal that interposes mandatory registration before viewing an article.

- Audience. The audience for H.W. Wilson databases is composed of high school students, undergraduate students, graduate students, educators, librarians, researchers, and the general public. Of these, undergraduate students are the most important users.

- Scope. The subject matter of open access journals should correspond to the range of disciplines covered by H.W. Wilson indexes.

- Indexability. Open access journals should contain indexable articles no shorter than a standard printed page.

- Reference value. Permanent reference value is required.

- Peer review. Peer review is required for open access journals. The journal should publish the names of its editorial advisory board members, together with their academic or scholarly affiliations. The members should represent a variety of institutions. Exclude publications where more than $50 \%$ of board members come from a single institution.

- Language. English or bilingual publications are preferable. If a journal is published in a foreign language, then informative English abstracts are required.

- Publishers. Publishers of open access journals should be organizations dedicated to the dissemination of scholarly information and research. These include colleges and universities, foundations, professional associations and societies, government agencies, other research institutions, and independent publishers committed to providing free access to peer-reviewed research. Open access publishers may be non-profit or for-profit.

- Authorship. Prefer journals whose authors come from a variety of institutions and geographic locations. Avoid "house organs", whose authors and editorial board members are predominantly affiliated with the journal's publisher.

- Abstracting. Prefer journals that provide informative author abstracts.

- International scope. Prefer journals that do not limit their geographic scope. Evidence of international scope can be ascertained in author affiliations, editorial board affiliations, article content, and references to works cited.

- Stable content. Open access journal web sites and their content must be stable and continuously available to the general public. 
broad acceptance of OAJ but does now include a few technical points as part of the criteria for inclusion such as set URLs for each article and not just for each issue of the journal.

For CILP the two primary criteria for inclusion in the index is the title is "associated with an accredited U.S. law school and being of a nature where indexing would be of a benefit."19 This allows them to focus on general law reviews which may have articles on a wide range of topics while not indexing specialty journals, e.g. journal on bankruptcy, which articles are selfevident. CILP has not 'ventured' into electronic journals as they feel their review process is not set up to handle the sporadic publishing pattern. ${ }^{20}$

CLI has sought to include OAJ that are from accredited U.S. law schools, but they have been slow in picking up other OAJ. This is a situation Michelle Pearse, a past chair and current member of the AALL Indexing of Periodicals Committee, comments they are seeking to address. ${ }^{21}$ The committee has a number of concerns and problems to overcome in reviewing OAJ at U.S. law schools for inclusion in the index. The most "interesting" [but probably actually the most frustrating] one from Pearse's point of view is the lack of clarity on the

- Archives. Previously published articles must be accessible and organized by date of publication or issue number. Archives must provide author names and titles of articles. Archives that provide searchability without an organized listing of articles are not acceptable.

- Frequency. Open access journals follow many different publication patterns. Some publish articles grouped as complete issues; others publish articles as they are received and reviewed. Regardless of the method, articles should be added on a regular basis. The total number of articles per year should be roughly predictable. Journals must produce at least one issue annually to be considered. Exclude journals that have no stated frequency.

- Publication alerts. Prefer journals that provide an email alerting service to announce the appearance of new issues. Email alerts are required for journals that publish individual articles rather than entire issues.

- URLs. Each article must be assigned its own URL so that H.W. Wilson e-journal hotlinks take the user directly to the desired article, not to the site of the issue as a whole. Do not add journals where a single URL is assigned to the entire issue.

- Graphic design. Open access web sites should be quick to load, easy to navigate, and highly readable.

${ }^{19}$ Email from Jonathan A. Franklin, Associate Law Librarian, University of Washington to Edward T. Hart, Assistant University Librarian, University of Florida (7 Oct 2009, 11:26 AM) (on file with author).

${ }^{20}$ Ibid.

${ }^{21}$ Email from Michelle Pearse, Librarian for Open Access and Scholarly Communication, Harvard Law School Library to Edward T. Hart, Assistant University Librarian, University of Florida (9 May 2008, 10:58 AM) (on file with author). 
journals web sites that they are open access and the availability of content. ${ }^{22}$ Additionally, as student run organizations, law reviews change policies nearly as frequently as they change editors come on board. ${ }^{23}$ Still Pearse's goal is the CLI to expand its coverage of adopting current standards such as requiring quality-control and predictable publication patterns so that more OAJ are indexed. $^{24}$

IFLP's general editor Tom Reynolds says indexing open access is a question that comes up often. ${ }^{25}$ As the titles come to their attention they look at them careful considering their quality control and knowledge of the publisher or institution. As IFLP is focused on foreign and international law, coverage of these dominates selection. Regardless of format, when considering a foreign journal and its coverage is its domestic law, the selectors for ILP weigh their current coverage of the country or region and the substance of articles and knowledge of the publisher. ${ }^{26}$ In other words, focus is more on quality journals with good coverage than trying to index every possible title.

\section{Study of Inclusion of DOAJ Law Journals in Indexes}

Looking at the sixty-one titles in the Directory of Open Access Journals during the month of June 2009 the following raw numbers can be reported. Fifteen titles were indexed at least once. CILP indexes nine. CLI indexes seven. ILP had the most coverage indexing twelve.

\footnotetext{
22 Ibid.

23 Ibid.

${ }^{24}$ Ibid.

${ }^{25}$ Email from Thomas Reynolds, General Editor, Index to Legal Periodicals to Edward T. Hart, Assistant University Librarian, University of Florida (3 Oct 2010, 7:19 PM) (on file with author).

${ }^{26}$ Ibid.
} 
IFLP indexes only one of the titles. The six titles indexed by CILP, CLI, and ILP are all from U.S. accredited law schools.

Of the non-United States OAJ, only two are indexed by the four indexes. The International Journal of Communications Policy and Law is indexed by ILP, and probably so because it is published by the Centre for Socio-Legal Studies at Oxford University. The other title is Juridica International which is indexed in IFLP and is published by the Law Faculty at the University of Tartu.

Looking at languages other than English, only journal indexed that possibly contains articles in other languages is Juridica International. The lack of indexing by the U.S. indexers of foreign language OAJ deny U.S. scholars the ability to even locate materials they might be able to read or important enough to seek out translation.

That leaves forty-six quality-controlled, regularly published open access legal journals not indexed by the leading U.S. legal indexes.

\section{Conclusion}

The typical legal researcher in the United States depends upon these four indexes for access to articles. As this study reveals researchers could be missing out on relevant content. As more open access journals are published, a trend supported by the law library community in such declarations as the Durham Statement, this absence of a traditional access point to articles becomes a greater obstacle for the legal community to exchange ideas and thoughts. 
The forty-six titles not indexed by the mainstream U.S. indexes are nearly good as lost. The saving grace is the accessibility via the DOAJ, but that site lacks the value added by indexers. Researchers who do come across the DOAJ are limited to keyword searching the text of these journals and having to do so in the language of the publication. Articles are not being reviewed by indexers to identify subjects that possibly classify the articles using headings not discoverable by key searching.

Much like Yontz and Fisher found in the library science literature, legal scholars in the U.S. who depend on indexes are missing out on rich content from around the globe particularly in areas that lend themselves to comparative study. Part of the concern here is the lack of inclusion by three indexes, CILP, ILP, and CLI, of foreign titles, especially not ones in English. IFLP is the natural indexer for picking up many of the current titles in DOAJ, but their resources would probably be overwhelmed to digest all this new content.

What is a researcher to do? Aside from the observation that law librarians inform their scholars about DOAJ, an idea that come to mind includes the analysis of the incorporation of open access legal journals in other indexes, particularly those covering other jurisdictions. Law Journals Index published in Great Britain by Sweet and Maxwell is an example, and it is available in academic Westlaw accounts used by U.S. law schools. Another idea for researchers who do discover useful materials in these OAJ is bring those titles to the attention of law librarians or submit journal titles directly to the selection committees of the indexes.

In the mean time, the selection committees of these indexes need to review and continue to evaluate their policies to seek broad inclusion of open access legal journals. If they, along with the rest of the law librarian profession, are to believe and support Richard Danner and the 
proponents of the Durham Statement, we need to ponder how we are access the fathomless depths of legal information in an era of open access. 


\begin{tabular}{|c|c|c|c|c|}
\hline Titles & $\begin{array}{l}\text { Current } \\
\text { Index to } \\
\text { Legal } \\
\text { Periodicals }\end{array}$ & $\begin{array}{l}\text { Current } \\
\text { Law } \\
\text { Index }\end{array}$ & $\begin{array}{l}\text { Index to } \\
\text { Legal } \\
\text { Periodicals } \\
\end{array}$ & $\begin{array}{l}\text { Index to } \\
\text { Foreign } \\
\text { Legal } \\
\text { Periodicals }\end{array}$ \\
\hline \multicolumn{5}{|l|}{ Acta Societatis Martensis } \\
\hline \multicolumn{5}{|l|}{$\begin{array}{l}\text { Alfa Redi : Revista de Derecho } \\
\text { Informático }\end{array}$} \\
\hline \multicolumn{5}{|l|}{ Ancilla Iuris } \\
\hline \multicolumn{5}{|l|}{$\begin{array}{l}\text { Anuario Mexicano de Derecho } \\
\text { Internacional }\end{array}$} \\
\hline Asian-Pacific Law \& Policy Journal & & & Y & \\
\hline $\begin{array}{l}\text { The Connecticut Public Interest Law } \\
\text { Journal }\end{array}$ & $\mathrm{Y}$ & & & \\
\hline Duke Environmental Law \& Policy & $\mathrm{Y}$ & $\mathrm{Y}$ & $\mathrm{Y}$ & \\
\hline $\begin{array}{l}\text { Duke Journal of Comparative and } \\
\text { International Law }\end{array}$ & $\mathrm{Y}$ & $\mathrm{Y}$ & $\mathrm{Y}$ & \\
\hline $\begin{array}{l}\text { Duke Journal of Gender Law \& } \\
\text { Policy }\end{array}$ & $\mathrm{Y}$ & $\mathrm{Y}$ & & \\
\hline Duke Law Journal & $\mathrm{Y}$ & $\mathrm{Y}$ & $\mathrm{Y}$ & \\
\hline \multicolumn{5}{|l|}{$\frac{\text { E Law - Murdoch University }}{\text { Electronic Journal of Law }}$} \\
\hline \multicolumn{5}{|l|}{$\begin{array}{l}\text { Electronic Journal of Comparative } \\
\text { Law }\end{array}$} \\
\hline \multicolumn{5}{|l|}{$\begin{array}{l}\text { Entertainment and Sports Law } \\
\text { Journal }\end{array}$} \\
\hline \multicolumn{5}{|l|}{$\begin{array}{l}\text { Erasmus Law and Economics } \\
\text { Review }\end{array}$} \\
\hline \multicolumn{5}{|l|}{ Estudios Constitucionales } \\
\hline \multicolumn{5}{|l|}{ European Journal of Legal Studies } \\
\hline Federal Courts Law Review & & & $\mathrm{Y}$ & \\
\hline \multicolumn{5}{|l|}{ Forum Historiae Iuris } \\
\hline \multicolumn{5}{|l|}{ Gaceta Laboral } \\
\hline Harvard Human Rights Journal & $\mathrm{Y}$ & $\mathrm{Y}$ & $\mathrm{Y}$ & \\
\hline \multicolumn{5}{|l|}{ Historia Constitucional } \\
\hline \multicolumn{5}{|l|}{$\begin{array}{l}\text { Hoechstrichterliche Rechtsprechung } \\
\text { im Strafrecht }\end{array}$} \\
\hline \multicolumn{5}{|l|}{ Human Rights \& Human Welfare } \\
\hline \multicolumn{5}{|l|}{$\underline{\text { IDP }}$} \\
\hline International Journal of Baltic Law & & & & \\
\hline
\end{tabular}




\begin{tabular}{|c|c|c|c|c|}
\hline Titles & $\begin{array}{l}\text { Current } \\
\text { Index to } \\
\text { Legal } \\
\text { Periodicals }\end{array}$ & $\begin{array}{l}\text { Current } \\
\text { Law } \\
\text { Index }\end{array}$ & \begin{tabular}{|l} 
Index to \\
Legal \\
Periodicals
\end{tabular} & $\begin{array}{l}\text { Index to } \\
\text { Foreign } \\
\text { Legal } \\
\text { Periodicals }\end{array}$ \\
\hline $\begin{array}{l}\text { International Journal of } \\
\text { Communications Law and Policy }\end{array}$ & & & Y & \\
\hline \multicolumn{5}{|l|}{$\begin{array}{l}\text { International Journal of Not-for- } \\
\text { Profit Law }\end{array}$} \\
\hline \multicolumn{5}{|l|}{$\begin{array}{l}\text { The Internet Journal of Law, } \\
\text { Healthcare and Ethics }\end{array}$} \\
\hline \multicolumn{5}{|l|}{ Italian Labour Law e-journal } \\
\hline \multicolumn{5}{|l|}{ Ius et praxis (En línea) } \\
\hline \multicolumn{5}{|l|}{$\begin{array}{l}\text { The Journal of Academic Legal } \\
\text { Studies }\end{array}$} \\
\hline \multicolumn{5}{|l|}{$\begin{array}{l}\text { Journal of Autoimmune Diseases } \\
\text { (JAD) }\end{array}$} \\
\hline \multicolumn{5}{|l|}{$\begin{array}{l}\text { Journal of Information, Law and } \\
\text { Technology }\end{array}$} \\
\hline \multicolumn{5}{|l|}{$\begin{array}{l}\text { Journal of International Commercial } \\
\text { Law and Technology }\end{array}$} \\
\hline \multicolumn{5}{|l|}{$\begin{array}{l}\text { The Journal of Philosophy, Science } \\
\text { and Law }\end{array}$} \\
\hline Juridica International & & & & $\mathrm{Y}$ \\
\hline \multicolumn{5}{|l|}{ Jurisprudence } \\
\hline \multicolumn{5}{|l|}{ JurPC } \\
\hline Law and Contemporary Problems & $\mathrm{Y}$ & $\mathrm{Y}$ & $\mathrm{Y}$ & \\
\hline \multicolumn{5}{|l|}{$\begin{array}{l}\text { Law, Environment and Development } \\
\text { Journal }\end{array}$} \\
\hline \multicolumn{5}{|l|}{$\begin{array}{l}\text { Law, social justice \& global } \\
\text { development }\end{array}$} \\
\hline \multicolumn{5}{|l|}{ Lex et Scientia } \\
\hline $\begin{array}{l}\text { Michigan Telecommunications and } \\
\text { Technology Law Review }\end{array}$ & Y & & $\mathrm{Y}$ & \\
\hline New England Law Review & $\mathrm{Y}$ & $\mathrm{Y}$ & $\mathrm{Y}$ & \\
\hline \multicolumn{5}{|l|}{$\begin{array}{l}\text { Northwestern Journal of Technology } \\
\text { and Intellectual Property }\end{array}$} \\
\hline \multicolumn{5}{|l|}{ Papers Lextra } \\
\hline \multicolumn{5}{|l|}{ Política Criminal } \\
\hline \multicolumn{5}{|l|}{ Revista CENIPEC } \\
\hline \multicolumn{5}{|l|}{ Revista Chilena de Derecho } \\
\hline Revista de Derecho & & & & \\
\hline & & & & \\
\hline
\end{tabular}




\begin{tabular}{|c|c|c|c|c|}
\hline Titles & $\begin{array}{l}\text { Current } \\
\text { Index to } \\
\text { Legal } \\
\text { Periodicals }\end{array}$ & $\begin{array}{l}\text { Current } \\
\text { Law } \\
\text { Index }\end{array}$ & $\begin{array}{l}\text { Index to } \\
\text { Legal } \\
\text { Periodicals }\end{array}$ & $\begin{array}{l}\text { Index to } \\
\text { Foreign } \\
\text { Legal } \\
\text { Periodicals }\end{array}$ \\
\hline \multicolumn{5}{|l|}{$\begin{array}{l}\text { Revista de estudios histórico- } \\
\text { jurídicos }\end{array}$} \\
\hline $\begin{array}{l}\text { Richmond Journal of Law and } \\
\text { Technology }\end{array}$ & & & $\mathrm{Y}$ & \\
\hline \multicolumn{5}{|l|}{ Rutgers Journal of Law and Religion } \\
\hline \multicolumn{5}{|l|}{ SCRIPT-ed } \\
\hline \multicolumn{5}{|l|}{ Stanford Technology Law Review } \\
\hline \multicolumn{5}{|l|}{$\begin{array}{l}\text { Unbound : Harvard Journal of the } \\
\text { Legal Left }\end{array}$} \\
\hline \multicolumn{5}{|l|}{$\begin{array}{l}\text { University of Ottawa Law and } \\
\text { Technology Journal }\end{array}$} \\
\hline \multicolumn{5}{|l|}{ Utrecht Law Review } \\
\hline \multicolumn{5}{|l|}{$\begin{array}{l}\text { War Crimes, Genocide and Crimes } \\
\text { Against Humanity }\end{array}$} \\
\hline Web Journal of Current Legal Issues & & & $\mathrm{Y}$ & \\
\hline $\begin{array}{l}\text { Zeitschrift für Internationale } \\
\text { Strafrechtsdogmatik }\end{array}$ & & & & \\
\hline
\end{tabular}




\section{Appendix B: Law Titles in the Directory of Open Access Journals}

Acta Societatis Martensis

Publisher: Martens Society

Language: English, Estonian

Start year: 2005

Alfa Redi : Revista de Derecho Informático

Publisher: Comunidad Alfa-Redi

Language: Spanish, Portuguese, English

Start year: 1998

Ancilla Iuris

Publisher: Ancilla Iuris

Language: German, English

Start year: 2006

Anuario Mexicano de Derecho Internacional

Publisher: Instituto de Investigaciones Jurídicas

Language: English, Spanish, French

Start year: 2001

Asian-Pacific Law \& Policy Journal

Publisher: William S. Richardson School of Law, Univ. of Hawaii

Language: English

Start year: 2000

The Connecticut Public Interest Law Journal

ISSN: d0000043

Publisher: The University of Connecticut School of E Law - Murdoch University Electronic Journal of Law

Language: English

Keywords: law

Start year: 2001
Duke Environmental Law \& Policy

ISSN: 10643958

Publisher: Duke University School of Law

Language: English

Keywords: law, environmental law

Start year: 1991

Duke Journal of Comparative and International Law ISSN: 10536736

Publisher: Duke University School of Law

Language: English

Keywords: law

Start year: 1997

Duke Journal of Gender Law \& Policy

ISSN: 10901043

Publisher: Duke University School of Law

Language: English

Keywords: law, gender

Start year: 1997

Duke Law Journal

ISSN: 00127086

Publisher: Duke University School of Law

Language: English

Keywords: law

Start year: 1997
Law

ISSN: 13218247

Publisher: Murdoch University, School of Law

Language: English

Keywords: law

Start year: 1993 
Electronic Journal of Comparative Law

ISSN: 13873091

Publisher: Tilburg University Schoordijk Institute

Language: English, French, German

Keywords: methodology of comparative law

Start year: 1997

Entertainment and Sports Law Journal

ISSN: 1748944X

Subject: Sports Science --- Law

Publisher: Electronic law journals project

Language: English

Keywords: socio-legal studies, football, entertainment law

Start year: 2005

Erasmus Law and Economics Review

ISSN: 18243886

Publisher: Erasmus Law and Economics Students

Society

Language: English

Keywords: law, economics

Start year: 2004

Estudios Constitucionales

ISSN: 07180195

Publisher: Centro de Estudios Constitucionales

Language: Spanish

Keywords: constitutions, constitutional law, government

Start year: 2006

European Journal of Legal Studies

ISSN: 19732937

Publisher: European University Institute

Language: all EU official languages
Federal Courts Law Review

ISSN: 19362463

Publisher: Federal Courts Law Review

Language: English

Keywords: law

Start year: 1998

Forum Historiae Iuris

ISSN: 18605605

Publisher: FHI

Language: German, English, French

Keywords: legal history

Start year: 1997

Gaceta Laboral

ISSN: 13158597

Publisher: Universidad del Zulia

Language: Spanish

Keywords: law, political science

Start year: 2005

Harvard Human Rights Journal

ISSN: 10575057

Publisher: Harvard Law School

Language: English

Keywords: human rights, civil rights

Start year: 1999

Historia Constitucional

ISSN: 15764729

Publisher: Universidad de Oviedo, Centro de

Estudios Politicos y Constitucionales

Language: Spanish, English, French, German, Italian, Portuguese

Keywords: public law, legal history, modern history, contemporary history, political science

Keywords: legal theory, comparative law, European Start year: 2000

law, international law

Start year: 2007 
Hoechstrichterliche Rechtsprechung im Strafrecht ISSN: 18656277

Publisher: Gerhard Strate

Language: German

Keywords: criminal law, criminal procedure, civil rights

Start year: 2000

Human Rights \& Human Welfare

ISSN: 15330834

Publisher: University of Denver

Language: English

Keywords: human rights, human security, humanitarianism, development

Start year: 2001

IDP

ISSN: 16998154

Publisher: Universitat Oberta de Catalunya

Language: Spanish, Catalan

Keywords: Internet, Law, Politics

Start year: 2005

International Journal of Baltic Law

ISSN: 16489349

Publisher: Vytautas Magnus University (Lithuania)

Language: English, Lithuanian

Keywords: Baltic law

Start year: 2002

International Journal of Communications Law and

Policy

ISSN: 14396262

Publisher: Oxford University, Centre for Socio-

Legal Studies

Language: English

Keywords: law, communications law

Start year: 1998
International Journal of Not-for-Profit Law

ISSN: 15565157

Publisher: International Center for Not-for-Profit Law

Language: English

Keywords: civil society, law, legislation

Start year: 1998

The Internet Journal of Law, Healthcare and Ethics ISSN: 15288250

Publisher: Internet Scientific Publications, LLC

Language: English

Keywords: ethics, healthcare, medical law

Start year: 2000

Italian Labour Law e-journal

ISSN: 15618048

Publisher: Università degli studi di Bologna

Language: Italian, Spanish, English, French, German

Keywords: trade unions law, employment law, social security systems, international labour law, comparative labour law

Start year: 1999

Ius et praxis (En línea)

ISSN: 07172877

EISSN: 07180012

Publisher: Universidad de Talca, Facultad de Ciencias Jurídicas y Sociales

Language: Spanish

Keywords: legal sciences

Start year: 2002

The Journal of Academic Legal Studies

ISSN: 18620280

Publisher: University of Hannover

Language: English

Keywords: legal education, law, legal research, legal teaching

Start year: 2005 
Journal of Autoimmune Diseases (JAD)

ISSN: 17402557

Publisher: BioMed Central

Language: English

Keywords: autoimmunity, diabetes mellitus, rheumatoid arthritis, thyroiditis, multiple sclerosis

Start year: 2004

Journal of Information, Law and Technology

ISSN: 13614169

Publisher: University of Strathclyde, Centre for

Law, Computers and Technology

Language: English

Keywords: law

Start year: 1996

Journal of International Commercial Law and

Technology

ISSN: 19018401

Publisher: International Association of IT Lawyers

Language: English

Keywords: international commercial law, business law, IT law, information technology

Start year: 2006

The Journal of Philosophy, Science and Law

ISSN: 15498549

Publisher: The Journal of Philosophy, Science and

Law

Language: English

Keywords: philosophy, science, law

Start year: 2001

Juridica International

ISSN: 14061082

Publisher: Faculty of Law, University of Tartu,

Iuridicum Foundation

Language: English, German, French

Keywords: law

Start year: 1996
Jurisprudence

ISSN: $1512181 \mathrm{X}$

Publisher: Georgian Internet Academy

Language: Georgian, Russian, English

Keywords: law

Start year: 2002

JurPC

ISSN: 09371125

EISSN: 16155335

Publisher: Makrolog Content Management AG

Language: German, French, English

Keywords: law, informatics

Start year: 1997

Law and Contemporary Problems

ISSN: 00239186

Publisher: Duke University School of Law

Language: English

Keywords: law

Start year: 1996

Law, Environment and Development Journal

ISSN: 17465893

Publisher: International Environmental Law

Research Centre, School of Oriental and African Studies

Language: English, French

Keywords: environmental law, law and development

Start year: 2005

Law, social justice \& global development

ISSN: 14670437

Publisher: Electronic Law Journals Project, University of Warwick

Language: English

Keywords: social justice, law, human rights

Start year: 2000 
Lex et Scientia

ISSN: $1583039 \mathrm{X}$

Política Criminal

Publisher: University of Bucharest and Nicolae

ISSN: 07183399

Titulescu University

Publisher: Universidad de Talca, Campus Santiago

Language: English, French

Language: Spanish, Portuguese

Keywords: interdisciplinary, law, economics, public Keywords: public law, criminology, penal justice, administration

Start year: 2006 penal science

Start year: 2006

Michigan Telecommunications and Technology LawRevista CENIPEC

Review

ISSN: 07989202

ISSN: 15288625

Publisher: Universidad de Los Andes (Venezuela)

Publisher: University of Michigan

Language: Spanish

Language: English

Keywords: criminology, delinquency, deviation,

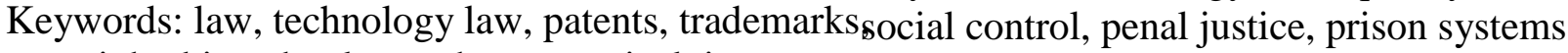

copyright, biotechnology, pharmaceutical, internet law

Start year: 2001

Start year: 1994

Revista Chilena de Derecho

New England Law Review

ISSN: 07160747

ISSN: 00284823

EISSN: 07183437

Publisher: New England School of Law

Language: English

Keywords: legal scholarship, law

Start year: 1995

Publisher: Pontificia Universidad Católica de Chile

Language: Spanish

Keywords: law, jurisprudence

Start year: 2006

Revista de Derecho

Northwestern Journal of Technology and IntellectualiSSN: 07169132

Property

ISSN: 15498271

EISSN: 07180950

Publisher: Northwestern University School of Law

Language: English

Publisher: Universidad Austral de Chile, Facultad de Ciencias Jurídicas y Sociales

Language: Spanish

Keywords: law, biotechnology, copyrights, Internet, Keywords: legal sciences

media, patents, telecommunications, trademarks

Start year: 2003

Start year: 2003

Papers Lextra

ISSN: 18852785

Publisher: Institut Joan Lluís Vives

Language: Catalan, English

Keywords: translation, interpreting, law, economics

Start year: 2005
Revista de estudios histórico-jurídicos

ISSN: 07165455

EISSN: 07176260

Publisher: Ediciones Universitarias de Valparaíso Language: Spanish

Keywords: social sciences

Start year: 1997 
Richmond Journal of Law and Technology

ISSN: 10917322

Publisher: University of Richmond School of Law

Language: English

Keywords: law

Start year: 1995

Rutgers Journal of Law and Religion

ISSN: d0000989

University of Ottawa Law and Technology Journal ISSN: 17106028

EISSN: 1715006X

Publisher: University of Ottawa, Faculty of Law Language: French, English

Keywords: law, technology

Start year: 2003

Publisher: Rutgers Law

Language: English

Keywords: law, religion

Start year: 1999

SCRIPT-ed

ISSN: 17442567

Publisher: AHRC Research Centre for Studies in Intellectual Property and Technology Law

Language: Multilingual

Keywords: law, technology, policy, ethics, intellectual property, information technology, medical law

Start year: 2004

Utrecht Law Review

ISSN: $1871515 \mathrm{X}$

Publisher: Igitur Publishing \& Archiving, Utrecht University Library

Language: English

Keywords: international law, comparative law

Start year: 2005

War Crimes, Genocide and Crimes Against

Humanity

ISSN: $1551322 \mathrm{X}$

EISSN: 15513238

Publisher: The Genocide Research Project \& Penn State Altoona

Language: English

Stanford Technology Law Review

ISSN: 10984267

Publisher: Stanford Law School

Language: English

Keywords: war crimes, international criminal law, genocide

Start year: 2005

Keywords: law, technology

Start year: 2004

Web Journal of Current Legal Issues

ISSN: 13601326

Unbound : Harvard Journal of the Legal Left

ISSN: 19323808

Publisher: Harvard Law School

Publisher: University of Newcastle

Language: English

Keywords: judicial decisions, law reform, legislation, legal research, legal information, information technology, information practice Start year: 1995

Keywords: social justice, critical left

Start year: 2005 
Zeitschrift für Internationale Strafrechtsdogmatik

ISSN: 18636470

Publisher: Editors of ZIS

Language: German, English, Spanish

Keywords: German criminal law, international

criminal aw, criminal procedure law

Start year: 2006 